\title{
Exploring customer participation and value
}

\author{
ALBERT JING-FUH YANG \\ Department of Marketing and Distribution Management, \\ National Kaohsiung University of Science and Technology \\ jfyang@nkust.edu.tw \\ TAIWAN \\ CHIA-WEN HUNG \\ College of management, National Kaohsiung University of Science \\ and Technology \\ tracychiawun@gmail.com \\ TAIWAN \\ SIAO- FEN HUANG \\ Department of Marketing and Distribution Management, \\ National Kaohsiung University of Science and Technology \\ u992581@gmail.com \\ TAIWAN
}

\begin{abstract}
Emerging marketing perspectives show that customer participation creates new opportunities for value creation. A perspective in the marketing section should be highlighted, a new opportunity must be emphasized, and customer participation should be used as a means to define the relationship benefits through their participation. The goal of customer participation is to create a high-value service process by creating cooperation with customers. This study describes and develops hypothesis verification. In the context of professional financial services in Taiwan, this study explores the effect of customer participation on value creation and satisfaction from customer and employee perspectives. It also analyzes the effects of different customer

capabilities and employees' emotional intelligence. The source of data collection is a total of 383 customer questionnaires from domestic financial institutions of two types of bank (public and private) to verify (1) how customer participation affects customer satisfaction and employee job satisfaction through relationship value creation, (2) how customer ability affects the relationship between value creation and satisfaction, and (3) how

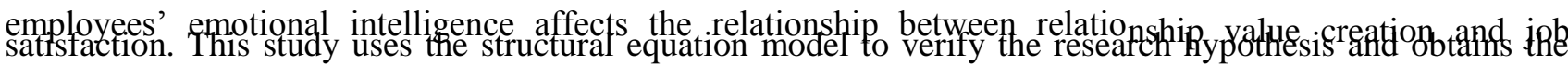
following results through empirical research: 1. Customer participation affects customer satisfaction through relationship value creation. 2. Customer participation does not completely create positive employee relationship value, which may increase work pressure. 3. Interference results show that customer ability can promote customer satisfaction, whereas employee emotional intelligence does not necessarily affect the relationship between employee relationship value creation and job satisfaction. These results contribute to the banking industry. Customer participation can promote value creation by arranging customers and financial specialists to have an appropriate interactive relationship and professional services.
\end{abstract}

Keywords: customer participation, customer satisfaction, employee job satisfaction, loyalty, organizational commitment, emotional intelligence

Received: July 12, 2020. Revised: November 30, 2020. Accepted: January 2, 2021. Published: January 24, 2021 


\section{Introduction}

As the economic structure changes, global banking services gradually grow in the industry. However, given the low barriers to enter in the banking service industry, a highly competitive service market has emerged. To maintain a competitive advantage, companies must innovate and provide various products and services to meet customer needs. Customer participation can increase the economic value of customers and strengthen the relationship between customers and employees; however, at the same time, it will also increase the work pressure of employees and affect their job satisfaction. In addition, the effect of customer participation on value creation depends on the cultural value of customers and service employees [1]. Marketing has inherited an exchange model from economics, which has a dominant logic based on the exchange of "commodities." Commodities are usually manufactured goods. In the past few decades, new ideas have emerged, and the revision logic of these ideas focuses on intangible resources, value creation, and relationships. In this logic, the provision of services rather than commodities is the basis of economic exchange [2]. Value co-creation is the premise of customer participation in the core principles of service-dominant logic and main logic. Customer engagement should bring value to customers and companies [3] and customers are often more satisfied with the value gained from service encounters [4]. This concept of creating value is especially important for professional services. For example, customer professional financial services participate in the decision of consultants and joint investment plans by providing information to their finances [4] .In this study, we test customer engagement with professional financial services and experience methods. We also promote service results by creating relationship value for customers and service employees in a Taiwanese business-toconsumer environment.

\subsection{Research Purposes and Issues}

Based on the above research background and motivation, this study will focus on cooperating with customers to develop value co-creation models to participate in professional financial services. We explore customer engagement to create value from the perspective of customers and employees. Therefore, the research questions are as follows:

(1) Will customer participation increase customer and employee satisfaction to create relationship value financial services for professionals and employees?

(2) Will customer loyalty with high customer satisfaction be different from that of customer with low customer satisfaction?

(3) Will organizational commitment with high employee job satisfaction be different from that of employees with low job satisfaction?

(4) Will customer ability and emotional intelligence affect the relationship

between value creation and satisfaction for customers and employees? 


\section{Literature Review and Variables}

This section initially introduces related literature and definitions about customer participation, relationship value creation between customers and employees, customer satisfaction, employee job satisfaction, customer loyalty, organizational commitment, role theory, customer capabilities, and emotional intelligence. Second, we review the literature, discussing the connections between variables, and further infer hypotheses.

\subsection{Customer Participation and Relationship Value Creation}

\subsubsection{Customer Participation}

Lengnick-Hall [5] referred to co-production as participants who engage customers to actively participate in an organizational work. Another concept of co-production is to enable customers to play a role in the service delivery process. On this basis, customer participation is a concept of coproduction. Both concepts emphasize the process of providing service to customers and employees. Issues of customer engagement have been discussed over the years by customers and service providers who can create high evaluation performance. Co-production can bring bilateral benefits to customers and employees. Such benefits include lower prices, more choice opportunities, and more discernment about the final product structure [6]. Lovelock and Wirtz [6] mentioned that some service companies can make processes more efficient and cost-effective and actively reduce the price through customer engagement.

\subsubsection{Relationship Value Creation}

The existing literature on relationship value creation provides evidence of value co-creation. Wilson [7] adopted a strategic point of view and indicated that companies should attach importance to the relationship value perceived by customers and define relationship value as the result of a cooperative relationship that can improve the competitiveness of partners. Wilson [7] stated that value creation is the process of developing trust and communication between partners to conduct mutually profitable transactions. Payne and Holt [8] indicated that relationship marketing should be added to the viewpoint of customer value, that is, relationship value. Therefore, relationship value emphasizes product, service, time, and psychological benefits [9]. This economic principle constitutes the core focus of most early customer participation research. The value of service results is created by collective efforts from the relationship between customers and providers [10] .Therefore, this study will focus on the value of the relationship between customers and employees that is established due to customer involvement.

\subsection{Customer Satisfaction and Customer Loyalty}

\subsubsection{Customer Satisfaction}

The existing literature provides evidence to discuss satisfaction. Many experiments have shown that satisfying behavior is a key result of buying and selling relationships [11]. Cardozo [12] presented the concept of customer satisfaction, Customer 
satisfaction will increase repurchase behavior. However, customer satisfaction in a business-tobusiness environment is often defined as a relationship between positive and emotional relationships with other companies by assessing aspects of the company's work.[13] In other words, when customers who have experienced a performance (or outcome) that has fulfilled their expectations [14] .Miller [15] claimed that customer satisfaction is determined by the customer's "expected degree" and "cognitive effectiveness," which interact with each other. Expectations and ideals are standards of product performance, which are used to measure the degree of actual product performance.

\subsubsection{Customer Loyalty}

Reichheld and Frederick [16] believed that customer loyalty has substantial benefits of cash value. Selnes [17] reported that customer loyalty includes the following four aspects: (1) the possibility of future purchases, (2) the continuation of the service contract, (3) the possibility of changing the brand, and (4) positive word-of-mouth publicity. Parasuraman, Zeithaml, and Berry [18] defined loyalty as "Besides my repurchase willingness, I am also willing to recommend to others and give positive reviews." Drake [19] argued that organizations must invest in customer loyalty to increase sales profits, market share, and stock prices through mouth-tomouth behavior. Griffin [20] advocated that customer loyalty must include frequent repetitive purchases, willingness to patronize other products or services offered by the company and establish the company's reputation, and being immune to promotions in other industries.

\subsection{Description of Organizational}

\section{Commitment, Customer Ability, and}

\section{Emotional Intelligence}

\section{Organizational Commitment}

Robbins and Judge [21] believed that organizational commitment implies that employees identify with a specific organization and its goals and hope to become or maintain the status of an organization member. The emotion of the organization and the recognition of the values of the organization are the golden rules for measuring employee commitment. Employees with organizational commitment will not be retreated from work even if they feel a little dissatisfied because they have loyalty and emotion to the organization. For example, if employees are unhappy with their current job, as long as they have a high degree of organizational commitment, then they will be willing to make some sacrifices for the organization. Robbins and Judge [21] also mentioned that organizational commitment can give employees trust in the organization, a sense of belonging, and unconditional contributions. Employees are under pressure at work, and they hope to get the same treatment. Wang [22] indicated that through a fair performance system, organizational commitments can bring substantial value to employees. Employees who are engaged in work will work harder to sacrifice and work for the organization. Thus, organizational commitment is the most important.

\subsubsection{Customer Ability}

The concept of customer competence comes from the connotation of customer preparation. Meuter [23] advocated that customer readiness affects customers' use of self-service technology, even though the state and extent of customer readiness is innovative. It includes role dominance, 
character abilities, and motivation. It also includes role explicitness, role ability, and motivation. Role ability is the capacity to execute tasks, which includes skills and confidence [24]. Thus, customer participation in the service delivery process requires customers' abilities [25] On the basis of the above literature, we develop some assumptions in this study.

\subsubsection{Emotional Intelligence}

Emotional intelligence refers to individuals' ability to understand their own emotions, observe and feel the emotional responses of others around them, and ability to manage and use emotions. It can be divided into (1) emotional cognition: individuals' assessment of their own emotions and of others; (2) emotion adjustment: ability to adjust one's own emotions and properly handle the emotions of others; and (3) emotion use: ability to perform flexible planning and having creative thinking, shifting attention, and stimulating motivation[26].Scholars define emotional intelligence from different viewpoints. Wong and Law [27] measured emotional intelligence by expressing one's emotions, knowing others' emotions, managing one's own emotions, and using emotions. Varca [28] measured emotional intelligence by introspective and interpersonal intelligence. The former includes attention to detail, frustration tolerance, alertness, planning, and flexibility; whereas the latter includes behavioral flexibility, empathy, listening, oral expression, persuasiveness, and social sensitivity. Emotional intelligence has a positive influence on employees' work attitude and behavior. Rozell, Pettijohn, and Parker[29] measured emotional intelligence with three dimensions, namely, emotional cognition, selfemotion management, and external emotional management, and used emotional intelligence and emotional orientation to predict sales staff's performance. Whether the banking industry can appropriately adjust the emotional intelligence requirements of employees and then use internal marketing management systems to improve employee performance after the event has become an important issue. Therefore, we establish a development hypothesis.

\subsection{Hypotheses and Theoretical Background}

With regard to creating value for customer engagement, the focus of this study is to create value for customers and employees. Previous studies have shown that participation can be intrinsically attractive [30] and enjoyable [31]. Parasuraman, Zeithaml, and Berry [18] indicated that further research is needed to enjoy the experience and enjoy the service. Therefore, customer engagement may increase communication and build relationships. Therefore, we assume that customer engagement creates value through positive satisfaction relationships. We propose the following hypotheses.

H1: Customer involvement positively affects customer relationship value creation.

$\mathrm{H} 2$ : Customer involvement positively affects employee value creation.

H3: Customer relationship value creation positively affects customer satisfaction.

H4: Employee relationship value creation positively affects employees' work.

\subsection{Effect of Customer Satisfaction on Customer Loyalty}

Many studies have shown that customer satisfaction affects customer loyalty and creates longterm relationships[32]. When customers are satisfied with the service provider, they will patronize or recommend the service provider to other customers. Heskett [33] claimed that loyalty will increase rapidly after customer satisfaction. On this basis, a strong 
correlation exists between customer satisfaction and customer loyalty. Thus, we assume the following.

H5: Customer satisfaction positively influences customer loyalty.

\subsection{Effect of Job Satisfaction on Organizational Commitment}

Heskett [33] proposed a service-profit chain, stating that employees' willingness to stay and work attitudes and employee-related organizational commitments will be met by internal service quality and employee influence. Loveman [34] also proposed a simplified service-profit chain model in an empirical research in the banking community to explore its relationship with employee satisfaction, organizational commitment, and financial performance. On this basis, a strong correlation exists between employee satisfaction and organizational commitment. Thus, we hypothesize the following.

H6: Employee job satisfaction positively influences organizational commitment.

\subsection{Moderator Effect of Customer Ability and Emotional Intelligence}

Schneider and Bowen [35] advocated that when customers have higher capabilities, they can provide information immediately, which will lead to higherquality cooperative production [4]. Customers should be serviced by experts, because experts can facilitate the effective implementation of services, and customers can provide accurate and appropriate information to employees. On this basis, a significant relationship exists between the ability and results of cooperative production. Thus, we propose the following.

H7: Customer ability positively moderate the relationship between customer relational value creation and customer satisfaction.
In many occupations, especially those with high levels of contact, emotional ability is critical to promoting performance[36]. Thus, a person with high emotional intelligence can likely control some interference or at least moderate them to an acceptable degree, thereby affecting performance (i.e., satisfaction). Thus, in this study, we expect emotional intelligence as moderator of employees' relational value creation and job satisfaction and generate the following hypothesis.

H8: Emotional intelligence positively moderates the relationship between employee relational value creation and employee job satisfaction.

Figure 1 shows the research framework of the eight hypotheses based on the literature. Moreover, it investigates moderating effects of customer ability and emotional intelligence.

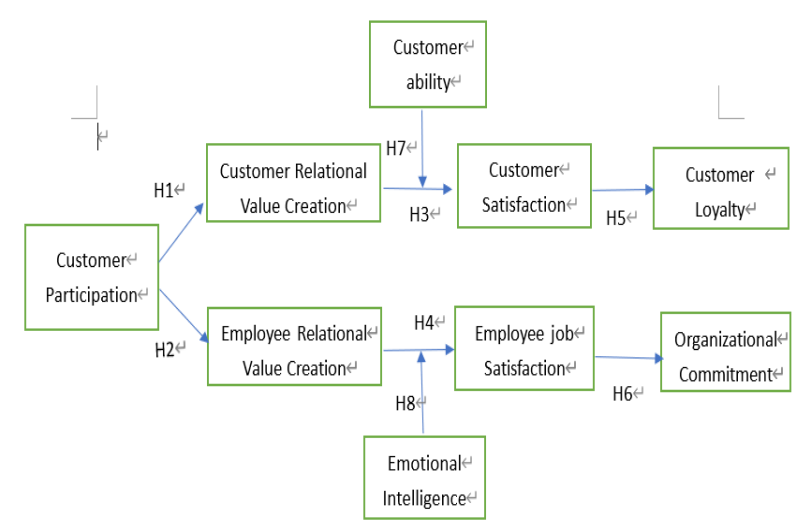

(Figure1 Research Framework)

\section{Research Method}

\subsection{Questionnaire Design and Measures}

On the basis of the above operational definitions, this study referred to several related documents and proposes measurement items and methods. The questionnaire is shown in Table 1. The variable measurement project was modified and developed by former scholars. The design of the questionnaire was 
divided into two versions, a version filled by the customer, which includes customer participation issues, customer relationship value creation, customer satisfaction, customer loyalty, and customer ability; and the other is what the financial consultant fills in, which contains the employee relationship value creation, employee job satisfaction, organizational commitment, and emotional intelligence. The measure was evaluated on a fivepoint scale (from 1 = strongly dissenting opinions to $5=$ strongly agreeing).

Table1 Questionnaire Design

\begin{tabular}{ll}
\hline Variable & Reference \\
\hline Customer participation & Auh et.al. (2007) \\
\hline Customer relational value & Hartline and Ferrell (1996) \\
\hline Customer satisfaction & Lam et.al. (2004) \\
\hline Customer loyalty & Zeithaml (1996) \\
\hline Customer ability & Sharma and Patterson (2000) \\
\hline Employee relation value & Hartline and Ferrell (1996) \\
\hline Employee job satisfaction & Hackman and Oldham (1975) \\
\hline Emotional intelligence & Schutte et. al. (1998) \\
\hline Organizational commitment & Mowday and Steers (1979) \\
\hline
\end{tabular}

\subsection{Data Collection and Analytical Method}

In this study, we used structural equation model for sampling and statistical analysis and analyzed data using Amos 18.0 software. After the questionnaire recovering, we examined and encoded the data artificially and then logged in the database. The questionnaire was filled out by a financial consultant who must select a specific service object from all of them as a matching customer who must have a professional process financial service. Descriptive statistical analysis was used to understand the demographic description of the respondents.

The target population of this study is mainly from Fortune Advisor Taiwan's top-15 domestic retail banks, including 7 public and 8 private banks. According to Banking Bureau, Financial Supervisory Commission, Executive Yuan, R.O.C, the top-15 Taiwan domestic retailing banks we selected, except industrial banks, were ranked by equities of 2011 in Taiwan. In addition, the questionnaire design of this study about customers and employees must form a correct relationship to avoid common method variations; thus, it has a corresponding number on each questionnaire, and the conditions are explained at the beginning of the questionnaire. Guaranteeing that pairs must be formed increased the difficulty of data collection; thus, we spent a total of three months in collecting the samples. During the process, we constantly reminded the respondents via telephone, and even visited financial advisors in person. In the end, we withdrew 450 pairs of customers and employees and 383 pairs of valid questionnaires.

\subsection{Sample Structure Description}

The data for this study came from 383 pairs of clients and financial advisors from public and private banks in Taiwan. We conducted a sample bank and seven private banks for eight public respondents. The details of the data are as follows. The sample structure for the financial advisors is as follows: the percentage of males and females is $35.2 \%$ (135) and $64.8 \%$ (248), respectively; the age level of most of the respondents is between 31 and 35 years old, which accounts for $36.6 \%$ (140); the most years of being a financial advisor is between 1 and 3 years, which account for $52.7 \%$ (202); the most service times within 1 month is between 5 and 7 times, which accounts for $44.1 \%$ (169); and the longest service life of this bank is $45.4 \%$ (174) from 1 year to 1 year and 3 years. The customer sample structure is as follows: the percentage of males and females was $39.9 \%$ (153) 
and $60.1 \%$ (230), respectively; the age level of most of the respondents is between 36 and 40 years old, which accounts for $32.6 \%$ (125); the education level of most of the respondents is college level $(71.8 \%$ (275)); the career of most of the respondents is business, which accounts for $43.1 \%$ (165); the salary of most of the respondents is between 50001 and 60000 (48\% (184)); the number of years of trade with financial advisors of most of the respondents is between 1 and 3 years, which accounts for 58.5\% (224); and the most number of discussion times with financial advisors within one month is between 2 and 4 times, which accounts for $60.8 \%$ (233).

\section{Research Results}

\subsection{Descriptive Analysis}

Table 2 shows some descriptive analysis of per dimension, including means, standard deviation (SD), Cronbach's alpha, construct reliability (CR), and average variance extracted (AVE). The average value of employee relations is $5.44(\mathrm{SD}=0.8)$. The average of the three questions about employee relationship value is between 5.41 and 5.47. The item with the highest average score is "I think customer involvement helps me build better relationships with customers" ( $\mathrm{M}=5.47, \mathrm{SD}=0.82)$. The average of employee job satisfaction is $5.01(\mathrm{SD}=0.79)$. The average of the four questions of employee job satisfaction is between 4.95 and 5.05. The project with the highest average score is "I like working in this bank" (M = 5.05, $\mathrm{SD}=0.81)$ The average value of EQ is $5.02(\mathrm{SD}=0.86)$. The average of the 13 questions of emotional intelligence is between 4.86 and 5.15. The item with the highest average score is "I seek activities that make me happy" $(\mathrm{M}=5.15, \mathrm{SD}$ $=0.86)$. The expected organizational commitment is $4.84(\mathrm{SD}=0.80)$. Most of the 11 issues of organizational commitment are between 4.61 and 4.99. The average value of customer engagement is $5.01(\mathrm{SD}=0.73)$. The average of the five questions that customers participated in is between 4.99 and 5.04. The project with the highest average score is "I always provide my employees with suggestions for improving service" $(\mathrm{M}=5.04, \mathrm{SD}=0.80)$. The average value of customer relationship is $5.02(\mathrm{SD}=$ 0.97). The average of the three questions about customer relationship value is between 4.98 and 5.05. Customer satisfaction is expected to be 5.02 ( $\mathrm{SD}=$ 0.47). The four customer satisfaction questions are expected to be between 4.98 and 5.06. On average, the highest item is "I am satisfied with this financial advisor"" $(\mathrm{M}=5.06, \mathrm{SD}=0.44)$. The mean of customer loyalty is 4.91 ( $\mathrm{SD}=0.60)$. The mean of five questions of customer loyalty ranges between 4.81 and 5.05 . The mean of customer ability is 5.02 $(\mathrm{SD}=0.96)$. The mean of four questions of customer ability ranges between 4.97 and 5.05. The item with the highest mean score is "I have ability to plan investment portfolio with this financial advisor" (M $=5.05, \mathrm{SD}=0.98$ ).

Table 2 Descriptive Analysis per Dimension

\begin{tabular}{lccccc}
\hline Dimension & Mean & SD & $\alpha$ & CR & AVE \\
\hline Customer & 5.01 & 0.731 & 0.853 & 0.86 & 0.55 \\
participation & & & & & \\
\hline Customer relational & 5.02 & 0.732 & 0.950 & 0.95 & 0.87 \\
value & & & & & \\
\hline Customer & 5.02 & 0.477 & 0.747 & 0.81 & 0.52 \\
satisfaction & & & & & \\
\hline Customer loyalty & 4.91 & 0.60 & 0.821 & 0.84 & 0.51 \\
\hline Customer ability & 5.02 & 0.96 & 0.973 & 0.97 & 0.89 \\
\hline Employee relational & 5.44 & 0.80 & 0.934 & 0.94 & 0.83 \\
value & & & & & \\
\hline Employee job & 5.01 & 0.79 & 0.924 & 0.93 & 0.77 \\
satisfaction & & & & & \\
\hline
\end{tabular}




\begin{tabular}{lccccc}
\hline Emotional & 5.02 & 0.86 & 0.980 & 0.98 & 0.79 \\
intelligence & & & & & \\
\hline Organizational & 4.84 & 0.80 & 0.963 & 0.96 & 0.71 \\
commitment & & & & & \\
\hline
\end{tabular}

Note: $\mathrm{SD}=$ Standard deviation, $\alpha=$ Cronbach's alpha, $\mathrm{CR}=$ Construct reliability, AVE $=$ Average variance extracted

\subsection{Validity}

In this study, confirmatory factor analysis was performed using Amos 18.0 to test the validity of the questionnaire. Construct validity can be divided into convergent validity and discriminative validity, which indicate the level of the reconstructed body or trait. Then, the convergent validity must meet three criteria: (1) the element load of the item must be between 0.5 and 0.95 , and the T-test must be significant [37]. (2) the CR must be higher than 0.6 [38]. (3) and every AVE must be higher than 0.5 [38]. As shown in Table 2, CR and AVE have met good standards for each factor load.

\subsection{Hypothesis Testing and Structure Model Results}

Table 3 shows other values about degrees of freedom. For GFI (0.826) and AGFI (0.802), the standard is $>0.8$; thus, the results are acceptable. For RMR (0.038) and RMESA (0.06), the standard is $<0.08$; thus, the results are acceptable. For NFI (0.912) and CFI (0.929), the standard is $>0.9$; thus, the results are acceptable. All of these meet the standards; thus, the overall measurement model is sufficient for validity testing. In addition, according to the results in Table 4, the customer participation path shows a significant positive influence on the value of customer relationship, which also supports H1. The influence of customer participation on the value of employee relationships is not positive; thus, $\mathrm{H} 2$ is not supported. Customer relationship value has a positive and significant influence on customer satisfaction, which supports H3. Employees have a significant positive influence on the relationship value of job satisfaction, which supports H4. Customer satisfaction has a positive and significant influence on customer loyalty, which supports H5. Employee job satisfaction has a positive and significant influence on organizational commitment, which supports H6. Except for SMC for employee relationship value and customer satisfaction, most SMCs are above 0.5 . Although the values of 0.43 and 0.47 , which are close to the standard, do not reach the value of 0.5 , they are still acceptable. Table 4 presents the details.

Table 3 Goodness of Fit, Standard, and the Value of this Model

\begin{tabular}{llll}
\hline Fit index & Standard & Results & $\begin{array}{l}\text { Goodness of } \\
\text { fit }\end{array}$ \\
\hline GFI & $>0.8$ & 0.83 & Acceptable \\
\hline AGFI & $>0.8$ & 0.81 & Acceptable \\
\hline CGI & $>0.9$ & 0.93 & Acceptable \\
\hline NFI & $>0.9$ & 0.91 & Acceptable \\
\hline PGFI & $>0.5$ & 0.726 & Acceptable \\
\hline RMSEA & $<0.08$ & 0.06 & Acceptable \\
\hline RMR & $<0.05$ & 0.038 & Acceptable \\
\hline
\end{tabular}


Table 4: Structural Model Results

\begin{tabular}{|c|c|c|c|}
\hline Hypothesis & Path & Expected & standardized \\
\hline & & symbol & solution \\
\hline \multirow[t]{2}{*}{ H1 } & C.P $\rightarrow$ & + & 0.899 \\
\hline & C.R. V & & \\
\hline \multirow[t]{2}{*}{$\mathrm{H} 2$} & C.P $\rightarrow$ & + & -0.053 \\
\hline & E.R.V & & \\
\hline \multirow[t]{2}{*}{ H3 } & C.R.V & + & 0.267 \\
\hline & $\rightarrow$ C.S & & \\
\hline \multirow[t]{2}{*}{$\mathrm{H} 4$} & E.R.V & + & 0.805 \\
\hline & $\rightarrow$ E.J.S & & \\
\hline \multirow[t]{2}{*}{ H5 } & C.S $\rightarrow$ & + & 0.774 \\
\hline & C.L & & \\
\hline \multirow[t]{2}{*}{ H6 } & E.J.S $\rightarrow$ & + & 0.524 \\
\hline & O.C & & \\
\hline
\end{tabular}

Table 4: Structural Model Results (Con.)

\begin{tabular}{lll}
\hline Hypothesis & $t$ value & Result \\
\hline H1 & $10.52^{* * *}$ & Supported \\
\hline H2 & -0.95 & Not supported \\
\hline H3 & $4.20^{* * *}$ & Supported \\
\hline H4 & $13.08^{* * *}$ & Supported \\
\hline H5 & $8.68^{* * *}$ & Supported \\
\hline H6 & $9.31^{* * *}$ & Supported \\
\hline
\end{tabular}

Note: $* p<0.05, * * p<0.01, * * * p<0.001$

C.P $=$ Customer participation; C.R.V = Customer relational value; $\mathbf{C} . \mathbf{S}=$ Customer satisfaction; $\mathbf{C} . \mathbf{L}=$ Customer loyalty; C.A.B = Customer ability; E.R.V

$=$ Employee relational value; E.J.S $=$ Employee job satisfaction; E.I = Emotional intelligence; O.C = Organizational commitment

\subsection{Result of Moderating Effect}

In the hierarchical regression analysis, we refer to the practice of Aiken and West [39] and added continuous control variables (basic demographic variables), independent variables (relational value), moderating variables (customer ability). and the interaction term between the variable and the moderating variable (relational value $*$ customer ability). The main purpose is to understand customer ability as a moderator of the relationship between customer relational value and customer satisfaction. The results are shown in Table 5. From the table, the interaction between customer relational value and customer abilities is significant. Thus, customer ability has an interference effect on the relationship between customer relational value and customer satisfaction. Moreover, the factor of the interaction term is positive, which is 0.130 . Hence, the higher the individual customer ability is, the greater the positive correlation between customer relational value and customer satisfaction will be. Therefore, $\mathrm{H} 7$ is supported. In the banking industry, especially in the field of professional financial management, customers who have good abilities are the focus. By assisting customers in investment and financial management and making the returns of these investments concrete and visible, they will make customers highly satisfied. Highly satisfied customers will also have high loyalty, which leads to the pursuit of sustainable value in the bank's investment part [39]. As shown in Table 6, this study also refers to the practice of Aiken and West [40]; in the hierarchical regression analysis we added continuous control variables (basic demographic variables), independent variables (relational value), and moderating variables (emotional Intelligence), 
and the interaction terms between independent variables and moderating variables (relational value * emotional intelligence). The audit results are shown in Table 6. From the table, the factor of the interaction term is negative, which is -0.054 . Thus, emotional intelligence has no moderating effect on the relationship between employee relational value and employee job satisfaction. In other words, $\mathrm{H} 8$ is not supported. Professional financial specialists facing customers with high ability often obey the company's strategy. Thus, they will adjust or hide the process of self-expression and emotional expression [41]. In the process of interpersonal interaction, the mental effort, planning, and control are needed to express the emotions required by the organization [42]. Moreover, emotional intelligence has no moderating effect on employee relational value and job satisfaction.

Table 5: Results of moderating effect of customer

\begin{tabular}{|c|c|c|c|c|}
\hline $\begin{array}{l}\text { Customer } \\
\text { satisfaction }\end{array}$ & $\begin{array}{l}\text { Control } \\
\text { variable } \\
\text { (Bank } \\
\text { classification) }\end{array}$ & $\begin{array}{l}\text { Moderating } \\
\text { variable } \\
\text { (Customer } \\
\text { ability) }\end{array}$ & $\begin{array}{l}\text { Independent } \\
\text { variable } \\
\text { (Relational } \\
\text { value) }\end{array}$ & $\begin{array}{l}\text { Interaction } \\
\text { term } \\
\text { (Relational } \\
\text { Value * } \\
\text { ability) }\end{array}$ \\
\hline Model1 & $-0.382^{* * *}$ & & & \\
\hline Model2 & $-0.384^{* * *}$ & & $0.139^{*}$ & \\
\hline Model3 & $-0.398^{* * *}$ & 0.440 & -0.282 & \\
\hline Model4 & $-0.397^{* * *}$ & $0.465^{*}$ & -0.25 & $0.130^{* *}$ \\
\hline
\end{tabular}

\subsection{Theoretical and Managerial Implications}

1. Motivate customers to become co-creators. In this process, companies need to motivate customers to participate. For customers with higher investment ability, more effort is required to help them visualize the relational value of their participation. Customers feel the value highlighted in the sustainable value provision. In addition, they should truly feel that they are different from other customers for them to see the 
direction of development and the unique offers they may have. For example, firms can have top private banking services, such as stocks, bonds, or funds, to provide customized investment themes where customers can choose the most suitable fee model according to their trading habits. Personal and professional financial planning should also be available for VIP customers. Trust planning for the wealth of VIP customers can also be offered so they can pass their accumulated achievements onto the younger generations. Promoting the creation of relationship value not only enhances the benefits of customer participation but also produces a competitive advantage for the firms [43].

2. Match customers and suitable employees. The dichotomy of culturally matching customers and employees helps maximize value creation. For services that require teamwork, this matching may be particularly feasible. Companies should evaluate the clients' investment value orientation and match a suitable financial advisor.

3. Improve employees' work ability, motivate employees and customers to create value together, and avoid abuses. Companies should let financial specialists realize the commercial value of the new method, the way in which it is responsible and the personal benefits it may bring. For example, organizational socialization can play a role in adapting specialists to accept customers as cocreators. The process may include changes to policies for recruiting, training, and rewarding employees to help customers in co-creation. In terms of avoiding malpractices, employees' ethics must be enhanced, and they should know that the bank is based on honesty and trust is the foundation of business. The government's financial management (Financial Supervisory Commission R.O.C.) will fix the internal control, manager culture, legal compliance, and corporate governance of all banks and review the entire system.

\subsection{Study Limitation}

The interpretation and application of the results are subject to some restrictions, and they will serve as recommendations for future research. This study has several limitations. First, the limitations of this study are related to the particular workplace of the sample. The study explores the role of co-creating value in Taiwan's financial advisors and clients. As a result, one should be extremely cautious while generalizing the results. Second, the research sample of this study has limitations on the professional financial advisors of the banking industry. Therefore, the sample of this study does not include the financial advisors of the insurance industry. We also limit financial advisors, and clients must have consulting experience. Therefore, this study does not consider the relationship of less than one year. Third, in this study, customers and employees must interact and create value together. Their attitudes and emotional reactions are likely to influence each other in the process of co-creation.

\subsection{Future Research}

On the basis of the findings and limitations of this study, the following recommendations are made for future research. First, future research should explore other industries or compare the differences between Western and Eastern organizations to summarize the results of this study. Second, the study focused on a professional service. Further research may consider other services of similar nature (e.g., medical and legal) and other service environments to determine the generalizability of the results. Professional financial services are highly credible, 
and for most customers, participation is high. Thus, customer engagement seems to be more likely to motivate customers to perceive value sources. However, in the case of low-input services, the value of customer participation to create opportunities may be reduced, which may lead customers to regard customer participation as a trivial matter and hold a cynical view, such that customer participation only provides a type of workload transferring to the customers. Third, based on the results of the study, the control variable "bank classification" has an important influence on the value creation and satisfaction of customers and employees. Therefore, further research may be conducted as a medium variable, and whether different results exist for public sectors bank and private bank may be discussed.

\section{Reference:}

[1] Bendapudi, Neeli and Robert P. Leone (2003), "Psychological Implications of Customer Participation in Coproduction," Journal of Marketing, Vol. 67, pp:14-28.

[2] Vargo, S. and R. Lusch(2004), “ Evolving to A New Dominant Logic for Marketing," Journal of Marketing, Vol.68. pp:1-17.

[3] Auh, Seigyoung, Simon J. Bell, Colin S. McLeod, and Eric Shih (2007), "Co-Production and Customer Loyalty in Financial Service," Journal of Retailing,Vol.83 No.3, pp:359-70.

[4]Ouschan, Robyn, Jillian Sweeney, and Lester Johnson (2006), "Customer Empowerment and Relationship Outcomes in Health care Consultations," European Journal of Marketing, Vol.40, No. 9-10, pp:1068-1086.

[5]Lengnick-Hall et al. (2000), From recipient to contributor: Examining customer roles and experienced outcomes, European Journal of Marketing, Vol 34,pp:359-383.
[6]Lovelock and Wirtz (2007), Services Marketing: People, Technology, Strategy, 7th edition, Journal of Services Marketing, Vol.18,No.5

[7] David T. Wilson (1995), "An Integrated Model of Buyer-Seller Relationships", Journal of the Academy of Marketing Science volume 23, Article number: 335

[8] Payne and Holt (2001)," Diagnosing Customer Value integrating the value process and relationship marketing", British Journal of Management, Vol. 12, 159-182

[9] Ravald \&Gronroos(1996),"The value concept and relationship" European journal of Marketing,

[10] Howard and Goodstein (1996), "Measuring customer value: Gaining the strategic advantage.”, Elsevier Inc.Vol 24, pp: 2-79

[11] Anderson, E.W., Sullivan, M.W., (1993), The antecedents and consequences of customer satisfaction for firms, Marketing Science, 12, pp.125-143

[12] Cardozo (1965), An Experimental Study of Customer Effort, Expectation, and Satisfaction, Journal of Marketing Research, Vol 8, PP:305314.

[13] Geyskens,Steenkap ,and Kumar (1999), A MetaAnalysis of Satisfaction in Marketing Channel Relationships, Journal of Marketing Research, Vol 36,No.3,PP:223-238.

[14] Kotler and Clarke (1987), "The extent of role differentiation among hospitals", Health Services Research, Vol. 16, pp:15-38.

[15] Merton H. Miller(1977) “DEBT AND TAXES", The Journal of Finance,Vol.32,pp:261-275

[16] Frederick F. Reichheld and W. Earl Sasser, Jr. (1990)"Zero Defections: Quality Comes to Services", Harvard Business Review.

[17] Selnes(1993)“'An Examination of the Effect of Product Performance on Brand Reputation, 
Satisfaction and Loyalty", European Journal of Marketing, Vol. 27, No. 9, pp. 19-35.

[18] Parasuraman ,Zeithaml and Berry (1994 )"Reassessment of Expectations as a Comparison Standard in Measuring Service Quality: Implications for Further Research", Journal of Marketing, Vol.58,No1.

[19] Drake (1998), Creating Integrated Curriculum: Proven Ways To Increase Student Learning., Corwin Press, Inc.

[20] Griffin (1996), The Human Side of Reengineering, Vol.18, issue5.

[21] Robbins and Judge (2019)," Organizational Behavior 18th Edition", Pearson Publisher.

[22] Yu-Ting Wang (2011), "The Relationship Among Organizational Communication, Incentive Systems, Leadership Style and Organizational Commitment Organizational Climate as a Mediator.", Department of Business Administration, National Kaohsiung University of Applied Sciences, Taiwan.

[23] Meuter, M., M. Bitner, A. Ostrom, and S. Brown (2005), "Choosing among alternative service delivery modes: An investigation of customer trial of self-service technologies," Journal of Marketing, Vol.69, No.2, pp: 61-83.

[24] Jayanti and Burn (1998), The antecedents of preventive health care behavior: An empirical study, Journal of the Academy of Marketing Science, Vol.26, No.6 .

[25] Hsieh, A., C. Yen, and K. Chih (2004), "Participative customers as partial employees and service provider workload," International Journal of Service Industry Management, Vol.15, No.2, pp: 187-199.

[26] Peter Salovey and John Mayer (1990), Emotional Intelligence, Journal Indexing and Metrics, Vol 9, Issue 3.
[27] Wong and Law (2020)," Wong and Law Emotional Intelligence Scale", American Psychological Association.

[28] Varca (2004)," Service skills for service workers: Emotional intelligence and beyond", Journal of Service Theory and Practice 14(6):457-467

[29] Rozell,Pettjohn and Parker (2006),'Emotional Intelligence and Dispositional Affectivity as Predictors of Performance in Salespeople" ,The Journal of Marketing Theory and Practice, Vol.14,No.2,pp:113-124

[30] Bateson, J.E.G. (1985) "Self-Service Consumer: An Exploratory Study", Journal of Retailing, Vol.61, No. 3, pp: 49-76.

[31] Dabholkar and Bagozzi (2002) An Attitudinal Model of Technology-Based Self-Service: Moderating Effects of Consumer Traits and Situational Factors, Journal of the Academy of Marketing Science, Vol.30,No.3,pp:184-201.

[32] Ganesan (1994), Determinants of Long-Term Orientation in Buyer-Seller Relationships, Journal of Marketing, Vol 58, Issue 2

[33] Heskett James L., Thomas O. Jones, Gary W. Loveman , W. Earl Sasser, Jr., and Hochschild, Arlie R. (1983), The Managed Heart: The Commercialization of Human Feeling, Berkeley University of California Press.

[34] Loveman (1998), Employee Satisfaction, Customer Loyalty, and Financial Performance: An Empirical Examination of the Service Profit Chain in Retail Banking, Journal of Service Research, Vol.1, No.1, pp:18-31.A

[35] Schneider and Bowen( 1995),Winning the Service Game, Handbook of Service Science, pp 31-59.

[36] Stough, C. \& De Guara (2003). Examining the relationship between emotional intelligence and job performance, paper presented at the 5th 
Industrial/ Organizational Psychology Conference, Melbourne, July.

[37] King, M. \& Gradner, D. (2006). Emotional intelligence and occupational stress among professional staff in New Zealand. International Journal of Organizational Analysis, 14(3), 186203.

[38] Fornell, C. and D. Larcker (1981), "Structural equation models with unobservable variables and measurement error: Algebra and statistics," Journal of Marketing Research, Vol.18, No.3,pp: 382-388.

[39] Markey(2020) ,"Are You Undervaluing Your Customers?", Harvard Business Review.

[40] Aiken and West (1991), Multiple Regression: Testing and Interpreting Interactions, SAGE Publication.

[41] Grandey(2000)," Emotion regulation in the workplace: A new way to conceptualize emotional labor", Journal of Occupational Health Psychology ,Vol.5,No.1,pp:95-110.

[42] Morris and Feldman (1996)," The Dimensions, Antecedents, and Consequences of Emotional Labor", The Academy of Management Review, Vol.21, No.4, pp:986-1010

[43] Bitner, Booms and Mohr (1994)," Critical service encounters: The employee's viewpoint", American Psychological Association.

\section{Creative Commons Attribution License 4.0 (Attribution 4.0 International , CC BY 4.0)}

This article is published under the terms of the Creative Commons Attribution License 4.0 https://creativecommons.org/licenses/by/4.0/deed.en _US 